\title{
Direct Assessment of Viral Aerosols on Cell Cultures
}

\author{
WILLIAM A. HANKINS AND HENRY J. HEARN \\ Aerobiology and Evaluation Laboratories, Fort Detrick, Frederick, Maryland 21701
}

Received for publication 10 April 1970

A technique is described for the direct exposure of cell cultures to airborne virus enabling quantitation of the virus in concentrations as low as one plaque-forming unit per liter of air.

Methods of sampling airborne microorganisms, particularly viruses, usually require their impingement in a suitable collection fluid although techniques may include collection on agar, on a filter, or electrostatic precipitation (4). The collected viral agent must then be quantitated by conventional assay procedures, i.e., by inoculation into laboratory animals, embryonated eggs, or cell cultures. This report describes a technique in which known volumes of viral aerosols were drawn directly into flasks containing cell culture monolayers that were then used to quantitate the virus by allowing plaques to develop. This technique permits the detection of as low as one plaque-forming unit (PFU) of airborne virus per liter of air.

Venezuelan equine encephalitis (VEE) virus, Trinidad strain, grown in embryonated eggs and the attenuated VEE virus described by Berge et al. (1) passaged 153 times in cell culture were selected for study. The data presented were obtained with the Trinidad strain since the same results were observed with the attenuated virus. Viral aerosols were generated with either an FK-8 gun (3) or a Collison device (2) in a cylindrical 1,200-liter chamber similar to that described by Wolfe (5). Monolayers of primary chicken embryo (CE) cells or an established line of guinea pig lung cells were prepared in $250-\mathrm{ml}$ cell culture flasks (Falcon Plastics, Los Angeles, Calif.) with Eagle's basal medium supplemented with $10 \%$ fetal calf serum, 100 units of penicillin, and $100 \mu \mathrm{g}$ of streptomycin per $\mathrm{ml}$. The CE cells were subsequently shown to be more uniformly susceptible to the virus and were chosen for most of the experimental work.

Cell cultures drained of growth media were exposed to the viral aerosols by attaching the mouth of the flask to the chamber. Before attaching the flask to the chamber, a hole was burned through the opposite end of the flask with a hot metal rod; a small sterile skirted stopper was inserted in this hole. A 15-gauge needle attached to a vacuum source by means of rubber tubing was used to penetrate the rubber stopper and to draw the aerosol into the flask. The rate of flow was controlled by a critical orifice inserted into the rubber tubing. When flasks were connected in series, this was accomplished by substituting metal caps containing 15-gauge needles and rubber gaskets for the plastic caps (Fig. 1).

After exposure to aerosols, cell monolayers were overlaid with Eagle's basal medium supplemented with $5 \%$ fetal calf serum (not heat-inactivated), $1 \%$ Noble agar (Difco), 100 units of penicillin, and $100 \mu \mathrm{g}$ of streptomycin per ml. The length of time after exposure before the overlay was applied did not appear to be critical, but it should be less than $1 \mathrm{hr}$. Infected cells were incubated for $24 \mathrm{hr}$ at $37 \mathrm{C}$; a second overlay containing, in addition, $0.01 \%$ neutral red was applied, and plaques were counted in another $24 \mathrm{hr}$.

Plaque counts were not diminished by an air wash of the flasks immediately after exposure to the aerosol, suggesting a rapid and irreversible attachment of the virus to the cells. Treatment of the exposed flask with specific antiserum reduced or eliminated plaque formation.

The titers shown in Table 1 are average values of at least two tests and represent values cor-

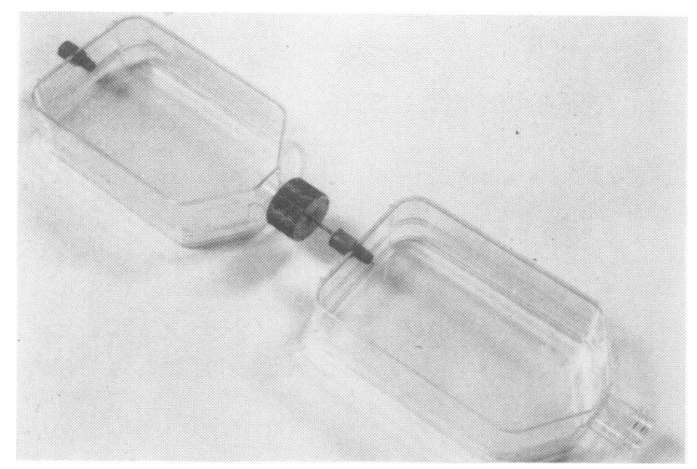

Fig. 1. Cell culture flasks used for direct assessment of viral aerosols. 
rected for a uniform total volume sampled. When virus diluted 1:300 was disseminated, the concentration of aerosolized virus as determined by the direct flask (DF) technique was approximately $2.6 \times 10^{3}$ PFU per liter. Dilution of the virus in 10-fold increments prior to aerosolization resulted in corresponding decreases in recoveries when the sampling rate was 1 liter per min. It is of interest that when the sampling rate was increased to 10 liters per min, the recovery titers decreased somewhat, suggesting that with this faster sampling rate some virus might have escaped from the flask. Titer values obtained by the impinger technique in Table 1 were comparable to those obtained by the DF technique in the same experiment. Aerosolized virus originating from suspension concentrations $1: 30,000$ or greater, however, were not detected with conventional impinger techniques.
TABLE 1. Sampling rates and recoveries of diluted aerosolized VEE virus with direct flask $(D F)$ and impinger (IMP) techniques

\begin{tabular}{|c|c|c|c|c|c|}
\hline \multirow{2}{*}{$\begin{array}{l}\text { Virus } \\
\text { dilution }^{a}\end{array}$} & \multirow{2}{*}{$\begin{array}{c}\text { Liter } \\
\text { per } \\
\text { min }^{b}\end{array}$} & \multirow{2}{*}{$\underset{(\min )}{\text { Time }}$} & \multirow{2}{*}{$\begin{array}{c}\text { Total } \\
\text { sample } \\
\text { volc } \\
\text { (liter) }\end{array}$} & \multicolumn{2}{|c|}{ PFU per liter } \\
\hline & & & & $\mathrm{DF}$ & $\mathrm{IMP}^{d}$ \\
\hline $1: 300$ & 1 & 0.1 & 0.1 & $2.6 \times 10^{3}$ & $2.6 \times 10^{3}$ \\
\hline \multirow[t]{3}{*}{$1: 3,000$} & 1 & 1.0 & 1.0 & $1.6 \times 10^{2}$ & $3.1 \times 10^{2}$ \\
\hline & 1 & 0.1 & 0.1 & 4.2 & $\mathrm{NT}^{e}$ \\
\hline & 10 & 0.1 & 1.0 & 0.7 & NT \\
\hline \multirow[t]{2}{*}{$1: 30,000$} & 1 & 10.0 & 10.0 & $1.1 \times 10^{1}$ & $\mathbf{N R}^{f}$ \\
\hline & 10 & 1.0 & 10.0 & 0.2 & NR \\
\hline $1: 300,000$ & 1 & 10.0 & 10.0 & $1.2 \times 10^{0}$ & NR \\
\hline
\end{tabular}

${ }^{a}$ In spray device prior to aerosolization.

${ }^{b}$ Liters per min limited by critical orifice used to draw aerosol into flask.

$c$ Total volume of air that passed through flask.

${ }^{d}$ Virus in impinger fluid assayed by plaque test.

e Not tested.

$f$ No virus recovered by conventional impinger technique.

TABLE 2. Sampling of VEE viral aerosols with flasks in series and impinger techniques ${ }^{a}$

\begin{tabular}{|c|c|c|c|c|c|c|c|}
\hline \multirow{2}{*}{ Sampling $^{b}$} & \multicolumn{5}{|c|}{ Plaques per flask } & \multirow{2}{*}{ Concn per liter ${ }^{c}$} & \multirow{2}{*}{ Concn per liter ${ }^{d}$} \\
\hline & Flask 1 & Flask 2 & Flask 3 & Flask 4 & Flask 5 & & \\
\hline Initial & $\mathrm{C}^{e}$ & $\mathrm{C}$ & $>750^{f}$ & 162 & 21 & $1.83 \times 10^{6}$ & $3.9 \times 10^{6}$ \\
\hline After first purge $g$ & C & $>800^{f}$ & 140 & 22 & & $1.62 \times 10^{5}$ & $1.95 \times 10^{5}$ \\
\hline After second purge & $>800^{f}$ & 95 & 3 & & & $9.80 \times 10^{3}$ & $2.38 \times 10^{4}$ \\
\hline After third purge & 123 & 16 & & & & $1.39 \times 10^{3}$ & $4.80 \times 10^{3}$ \\
\hline
\end{tabular}

a As used in direct flask technique (Fig. 1).

${ }^{b}$ One hundred milliliters of aerosol sampled in $0.1 \mathrm{~min}$.

c Assay values based upon countable plaques.

${ }^{d}$ Assay values based upon plaque counts obtained from impinger fluids.

e Clear, total cell destruction.

$f$ Too numerous to count; only an estimate was possible.

- Virus concentration reduced (purged) by air dilution of chamber.

The results of experiments designed to test for viral escape from flask exposed to aerosols of different concentrations are shown in Table 2 . In these tests, the aerosols were drawn through five flasks connected in series rather than into only one flask. Aerosol concentrations were reduced by a series of air dilutions (purges) of the chamber, and, after each purge, the virus titer of the aerosol was determined. Data indicate that about $10 \%$ of the virus bypassed one flask and was deposited in the next flask at all concentrations. Also included in Table 2 are data showing that the assessments of virus per liter of aerosol by the DF technique were approximately the same as obtained by assaying impinger samples by the plaque technique.

Results of these tests indicate that the direct exposure of cell culture monolayers to viral aerosols (DF technique) provides a simple and highly sensitive technique for the assessment of infectious airborne viral particles. The DF technique permitted the recovery of virus in very low aerosol concentrations that could not be detected by conventional impinger techniques.

\section{LITERATURE GITED}

1. Berge, T. O., I. S. Banks, and W. D. Tigertt. 1961. Attenuation of Venezuelan equine encephalomyelitis virus by in vitro cultivation in guinea pig heart cells. Amer. J. Hyg. 73:209-218.

2. Collison, W. E. 1935. Inhalation therapy technique, p. 77 Heineman, London.

3. Jemski, J. V., and G. B. Phillips. 1965. Aerosol challenge of animals, p. 286. In W. I. Gay (ed.), Methods of animal experimentation, vol. 1. Academic Press Inc., New York.

4. Wolf, H. W., P. Skaliy, L. B. Hall, M. M. Harris, H. M. Decker, L. M. Buchanan, and C. M. Dahlgren. 1959. Sampling microbiological aerosols. Public Health Monograph 60. U.S. Government Printing Office, Washington, D.C.

5. Wolfe, E. K. Jr. 1961. Quantitative characterization of aerosols. Bacteriol. Rev. 25:194-202. 